\title{
How do ditches contribute to bryophyte diversity in managed forests in East-Central Europe?
}

\author{
Monika Staniaszek-Kik ${ }^{1}$ Katarzyna M. Zielińska ${ }^{1}$ Małgorzata Misztal $^{2}$
}

Received: 24 January 2016/Revised: 13 April 2016/Accepted: 25 April 2016/Published online: 2 May 2016

(c) The Author(s) 2016. This article is published with open access at Springerlink.com

\begin{abstract}
The study focuses on identifying and assessing the effect of the presence of drainage and roadside ditches on the diversity of bryophytes in managed forests. We compared the composition of moss and liverwort species, their richness and abundance in plots that are located in ditches as well as corresponding control plots in the surrounding forests with regard to the forest type (coniferous, mixed and deciduous). ANOVA demonstrated the pronounced impact that the presence of ditches in managed forests has on an increase in bryophyte species richness. A comparison of forest and ditch types using DCA pointed to a correlation between the number of deciduous trees in the stands and an increased dissimilarity of ditch bryophytes when compared to the bryophytes of the corresponding control plots. Using the ecological indicator values, CCA confirmed the special significance of ditch settlements for hygrophilous species, which at present cannot otherwise find favorable conditions in managed forests. The study proves that ditches, and especially those with intermittent pools of stagnant water, may become a significant source of microhabitat diversity. Their presence may provide a welcome preserve for rare and protected species that cannot find suitable substrates in managed forests.
\end{abstract}

Keywords Mosses - Liverworts - Drainage ditches · Roadside ditches $\cdot$ Microhabitat diversity $\cdot$ Managed forests

Katarzyna M. Zielińska

kziel@biol.uni.lodz.pl

1 Department of Geobotany and Plant Ecology, Faculty of Biology and Environmental Protection, University of Lodz, Banacha 12/16, 90-237 Lodz, Poland

2 Chair of Statistical Methods, University of Lodz, Rewolucji 1905 r 41, 90-214 Lodz, Poland

\section{Introduction}

Changes in species diversity that are caused by human activity may result in two distinct patterns. One is the transformation of natural habitats that leads to the disappearance of species and the impoverishment of local flora (Gustafsson and Hallingbäck 1988; Andersson and Hytteborn 1991; Vellak and Paal 1999). The other consequence of change is the man-made contribution to the spread of alien species and the formation of new settlements that are open to expansive native species (Fudali 2006; Stebel 2006; Jukoniene 2008). Bryophytes constitute an element of vegetation that responds to changes in habitat conditions relatively quickly (Herben 1987; Slack 1990). Some species, especially taxa with a narrow ecological amplitude, decrease the area on which they occur, while others are successful in breaking into secondary settlements (Stebel 2006; Jukonienè 2008).

A relevant aspect of human activity for the preservation of the natural species diversity of bryophytes is forest management, which significantly modifies microhabitat and microclimate conditions and thus directly and indirectly impacts forest bryophytes (Gustafsson and Hallingbäck 1988; Andersson and Hytteborn 1991; Vellak and Paal 1999; Paillet et al. 2010; Vellak et al. 2003 and cited). The structure of managed forests is significantly simpler than that of natural forests (Kuuluvainen et al. 1996; Commarmot et al. 2005). They are frequently composed of even-aged stands with a poorly diversified species composition that lacks old trees, uprooted trees or large lying logs, the removal of which further contributes to the diminished diversification of the substrates that are available to bryophytes (Franklin et al. 2002).

One of the methods of managing the forest areas of the Central European Plain was to establish ditches in order to 
improve the productive capacity of soils (Hillman 1992; Roy et al. 2000). Due to a markedly lower level of groundwater in Polish Lowlands today as compared to the levels in the nineteenth and early twentieth centuries (Lipiński 2006), many forest ditches only evacuate water during spring thaws and intensive downpours. The majority of such ditches are not dredged and have become a location for lush vegetation growth (Zielińska et al. 2013). In forest areas, ditches are characterized by a considerable differentiation of the microhabitat, which is especially relevant for the diversity of bryophytes (Humphrey et al. 2002; Mills and Macdonald 2004; Cole et al. 2008; Márialigeti et al. 2009). Depending on the alignment of ditches relative to the points of a compass, locations with a quite varied light penetration index may coexist over a limited area. There are also pronounced differences in humidity regimes in ditches, especially between the bottom and the sides. Steep ditch sides are prone to mechanical damage that is caused by animals or humans, which invariably leads to the exposure of the soil surface. At the same time, the bottom of the ditch gathers plant debris and fine woody debris. Hence, a hypothesis could be formulated that a ditch that runs through a managed forest may become the site of an increased diversity of bryophyte species by providing the opportunity for the coexistence of a wide variety of microhabitats over a limited area. The hypothesis was validated by the findings of Ricklefs and Lovette (1999) as well as Steinmann et al. (2011) among others, who claim that a strong habitat-diversity effect can be observed in the case of taxa that show a high degree of habitat specialization, while for less demanding plants, the dependency of diversity-area will be much more significant. Since the majority of bryophytes are strictly connected with specific types of substrates and microhabitat conditions (Cole et al. 2008), it can be stated that a high probability of finding a correlation between bryophyte species richness and habitat diversification that is caused by the presence of ditches exists. In addition to the typical drainage ditches within managed forests, there are also roadside ditches, which as a rule form one drainage system. Roadsides with ditches are listed among the most species-rich habitats in forest areas (Baltzinger et al. 2011; Smith et al. 2007) and are also regarded as a potential route of plant dispersal (e.g., Flory and Clay 2009; Forman et al. 2003). This study considers the diversification of ditches into those that cross through the forest stand directly (called drainage ditches) and roadside ditches.

Numerous authors have discussed the substantial connection between stand composition and the diversity of ground layer flora, including bryophytes (Härdtle et al. 2003; Hokkanen 2006; Barbier et al. 2008; Ódor et al. 2013; Hart and Chen 2006 and those cited). Their research proves that conifers such as pine trees contribute to moss layer growth, while deciduous tree species create conditions that are favorable for the growth of vascular plants but inhibit the growth of mosses. Simultaneously, in comparison with single-species plantings, mixed stands facilitate species richness (Hill 1992). Over the area of Central Poland, where the research was conducted, the most common tree is Pinus sylvestris, which is frequently the only constituent of the canopy layer or grows along with the oak Quercus robur. On the other hand, deciduous forests are the least frequent forest type and often include species such as hornbeam Carpinus betulus, lime Tilia cordata and much more rarely beech Fagus sylvatica. Single white birch Betula pendula specimens, which spontaneously spread after clearcutting and are not always removed during subsequent forest management, are also frequent, especially along roads and ditches. The similarity of the type of soil in ditches and around them as well as a definitive pool of local plants that inhabit ditches after they have been dug justify the formulation of the hypothesis that the type of surrounding forest will significantly influence the species richness and composition of the ditches that are analyzed.

The following questions were asked:

1. Does the presence of ditches result in an increased diversification of mosses and liverworts in forests?

2. Does the type of forest stand (coniferous, deciduous or mixed) or ditch (drainage-roadside) have an impact on bryophyte species composition of the ditches?

3. Do bryophytes that inhabit ditches indicate different and more diversified settlement conditions than those that prevail in forest habitats?

\section{Methods}

\section{Study site}

The study was undertaken in managed forests that are located in the Central European Plain in the Polish Lowlands $\left(51^{\circ} 10^{\prime}-52^{\circ} 05^{\prime} \mathrm{N}, 19^{\circ} 05^{\prime}-20^{\circ} 15^{\prime} \mathrm{E}, 180-220 \mathrm{~m}\right.$ altitude), in an area of approximately $14,000 \mathrm{~km}^{2}$. Forests constituted about $20 \%$ of the surface of the area and were located among both agricultural and urban landscapes. These forests are predominantly pine forests and mixed pine-oak (Dicrano-Pinion) and less frequently deciduous stands (Carpinion) (Matuszkiewicz 2001).

\section{Data collection}

The study was conducted between 2007 and 2009 and covered two types of ditches: drainage ditches, which intersected with forest stand, and roadside ditches, which 
ran alongside the unpaved service roads that are used by the forest administration. The study only investigated ditches that had not been cleared or dredged for a period of at least five years and that had a minimum depth of $0.5 \mathrm{~m}$. The ditch depth ranged between 0.5 and $1.75 \mathrm{~m}$. In particular ditches, study plots were established at least a dozen meters from forest edges, clearcutting areas, buildings, etc. The areas where ditches crossed young stands (trees under 60 years) were omitted also. The plots were $5 \mathrm{~m}$ long and their width corresponded to the width of the ditch (1-5 m). An analogous (identically sized) corresponding control plot was established in the surrounding forest stand for each ditch plot. The control plot was located $10 \mathrm{~m}$ from the ditch plot in order to eliminate the influence of any enhanced lighting conditions that might be present near the ditches. A total of 61 pairs of corresponding (matched) plots were analyzed, i.e., 40 in drainage ditches and surrounding forests and 21 in roadside ditches and the forest surrounding them. Since managed forests display a simplified structure and altered species composition in comparison with natural forests, the study plots were given a simplified classification of coniferous, mixed or deciduous forests. Since the plots were established in randomly chosen ditches, the number of pairs of plots that are located in different types of forests and for different types of ditches is not equal, although it corresponds to the area that is occupied by different forest and ditch types in Central Poland (Table 1). Both the depth and width were noted for each ditch.

A detailed inventory of moss and liverwort species was made for each plot. The study included both terrestrial species and those that can grow on all available substrates (stones, decaying stumps and logs, fine woody debris as well as living trees; in the last case, the presence of bryophytes was usually observed up to $50 \mathrm{~cm}$ from the root base). The substrates on which the species were found were also noted. The cover for each species was specified based on the 10-point abundance scale according to Londo (1975). The general percentage of bryophyte layer coverage as well as plot shading by trees and shrubbery was noted for all of the plots. The species nomenclature for the mosses followed Ochyra et al. (2003), and for the liverworts, it followed Klama (2006). The list of species along with their frequency is attached as "Appendix".

\section{Data analysis}

The Spearman's rank correlation coefficients were applied during the preliminary studies to determine whether the width, depth, shrub and tree shading levels exert any significant influence on species richness and bryophyte coverage in ditches. Since the analysis did not yield unambiguous evidence toward a significant influence of the above-mentioned factors, the matched-pairs $t$ test was used to compare the differences between the species richness noted in ditches and in corresponding forest plots. The twoway ANOVA was used to analyze the differences between paired ditch-forest floor plots using ditch type and forest type as factors.

Multiple comparisons were done using Tukey's HSD test for unequal sample sizes. Normality was tested using the Shapiro-Wilk test for normality. The homogeneity of variances was verified using the Levene's test. Results were considered to be significant for $P<0.05$.

In order to better understand the differences in species composition and coverage between the different types of plots, we applied DCA.

Morisita's index of similarity and Bray-Curtis similarity measure were used to quantify the compositional similarity between the ditch and corresponding forest plot. Two-way ANOVA was applied to detect any differences between the similarity measures of the studied plots considering the two types of ditches and three types of forests.

To determine changes in the habitat preferences of bryophytes that were caused by the creation of ditches, the ecological diversification of the bryophytes that were recorded in the ditches and forests was also tested using Düll's ecological indicators (1992). The analysis focused on the preferences of particular species to five environmental factors: light (L), temperature (T), continentality of climate $(\mathrm{K})$, humidity (F) and substrate $\mathrm{pH}(\mathrm{R})$. Canonical correspondence analysis (CCA) was used to determine the relationships between the environmental conditions preferred by particular species and the different types of plots. To do this, the environmental variables were calculated as the average of Düll's ecological indicators weighted by the frequencies of the occurrence of a species in particular plot types. All calculations were performed using STATISTICA PL version 10.0 (StatSoft, Inc. 2011), CANOCO (Ter Braak and Smilauer 2002) and Past (Hammer et al. 2001).
Table 1 The number of analyzed pairs of plots in different types of forest stand and different types of ditches

\begin{tabular}{lcccc}
\hline Ditch types & Coniferous forests & Mixed forests & Deciduous forests & Total \\
\hline Drainage & 25 & 9 & 6 & 40 \\
Roadside & 8 & 8 & 5 & 21 \\
Total & 33 & 17 & 11 & 61 \\
\hline
\end{tabular}




\section{Results}

Among the 79 bryophyte taxa that were recorded, 72 species (including 12 liverworts) were found in ditches, whereas only 50 (9 liverworts) were found in the control plots in the forests (see "Appendix"). Twenty-nine of the species that were found (37\% of the identified bryophytes) were recorded only in ditch plots, while only seven $(9 \%)$ were found only in forest plots. However, an overwhelming majority of those taxa (44) displayed a low frequency (they were only recorded up to four times). Of the species that were recorded only in ditches, the most frequent were: Oxyrrhynchium hians (noted seven times), Aulacomnium palustre, Fissidens bryoides and Plagiomnium undulatum (noted four times), whereas the all species occurring only in corresponding plots in forests were recorded only once apart from Amblystegium serpens which was noted three times. Nine of the species that were found in both ditches and the corresponding control plots had a much higher frequency in ditches. These included Atrichum undulatum, Brachythecium rutabulum, Calypogeia azurea, Dicranella heteromalla, Lepidozia reptans, Plagiomnium affine, Plagiothecium denticulatum, Polytrichastrum formosum and Sphagnum fallax. There were only three species with a considerably higher frequency in forests. These were Orthodicranum montanum, Hypnum cupressiforme and Lophocolea heterophylla ("Appendix").

Among over one-third of the taxa which were found only in ditch plots, we could distinguish a large group of hygrophilous species such as Calliergon cordifolium, Pellia epiphylla, Sphagnum fimbriatum or Warnstorfia fluitans. The ditches were also distinct in respect of the presence of species preferring light-demanding habitats (Bryum caespiticium, Ceratodon purpureus, Polytrichum juniperinum or Polytrichastrum longisetum). On the steep ditch sides, especially in locations with exposed mineral soil, non-forest species with limited competition skills and preference for initial habitats were noted, e.g., small-size annual acrocarpous mosses: Pohlia melanodon, P. wahlenbergii, Bryum caespiticium and Funaria hygrometrica. Additionally, as a result of the accumulation of organic matter such as twigs, in ditches there occurred epixylic and epiphytic species such as Lepidozia reptans or Ulota crispa. For details, please see the "Appendix" in which the substrates of the species that were recorded have also been listed.

The mean species richness was significantly higher in ditches than in forest plots (difference: $3.08 \pm 3.89$ (SD), $t=6.18 ; d f=60 ; P<0.001)$. This means that the presence of ditches resulted in an increased diversification of mosses and liverworts in the forests. The differences between the paired ditch-forest floor plots were not statistically significant taking into account the forest types (ANOVA; $F=2.10 ; d f=2 ; P=0.1320$ ) and ditch types
(ANOVA; $\quad F=0.36 ; \quad d f=1 ; \quad P=0.5500$ ) (Table 2). However, a statistical significance did exist after considering all of the factors (ANOVA; $F=4.78 ; d f=2$; $P=0.0122$ ). Detailed analysis using multiple comparison tests (Tukey's method for unequal sample sizes) showed that a statistically significant difference was observed between the drainage ditches in mixed and deciduous forests (the mean difference between ditch and forest plots for the mixed forest was $5.00 \pm 5.50$, and for the deciduous forest, it was $-1.17 \pm 2.93 ; P=0.0500)$.

In order to better understand the pattern that was observed, the influence of ditch and forest type on species composition and coverage was analyzed using DCA (Fig. 1). It was demonstrated that with the increased participation of deciduous species in a stand, the dissimilarity of ditch bryophytes increased compared to the control plots in the forest. The dissimilarity was most pronounced with regard to the participation of bryophytes that inhabit tree trunks and decaying wood. Such species occurred with the greatest frequency in the control plots in deciduous forests (Aulacomnium androgynum, Brachytheciastum velutinum, Herzogiella seligeri, Hypnum cupressiforme, H. pallescens, Orthodicranum flagellare and Tetraphis pellucida). In the ditches, on the other hand, epigeic species such as Atrichum undulatum, Cephaloziella divaricata, Dicranella heteromalla, Kindbergia praelonga and Oxyrrhynchium hians were more frequent. Although we observed the same tendency in both the cases of the roadside and drainage ditches, the analysis of the compositional similarity indexes (Morisita's index and Bray-Curtis similarity measure) showed that the observed differences were not statistically important. Taking into account the forest types, we obtained: $F=3.12 ; d f=2 ; P=0.0520$ for Morisita's index and $F=2.80 ; d f=2 ; P=0.0693$ for Bray-Curtis similarity measure; for the influence of ditch type: $F=0.06 ; d f=1 ; P=0.8010$ (Morisita's index) and $F=0.33 ; d f=1 ; P=0.5684$ (B-C similarity measure); and for the interaction of forest and ditch types: $F=1.55$; $d f=2 ; P=0.2221$ and $F=1.15 ; d f=2 ; P=0.3240$ for Morisita's index and B-C similarity measure, respectively.

Canonical correspondence analysis (CCA) (Fig. 2) demonstrated that among all of the environmental factors, preference of bryophytes for humid sites distinguished the plots that are located in ditches from the control forest plots (regardless of the types of forests or ditches that were analyzed).

\section{Discussion}

The research that was conducted has indicated that the bryophyte flora that was found in ditches, both roadside and drainage, was considerably richer than those in the control forest plots. The increase in species richness that 
Table 2 Impact of the presence of ditches expressed in $\Delta N$, which is the difference between the number of species identified in the ditches and the number of species found in the control forest plots considering the forest type and ditch type

\begin{tabular}{lccccccc}
\hline Descriptive statistics & Mean & Median & Min & Max & Q25 & Q75 & SD \\
\hline Forest type & & & & & & & \\
$\quad$ Coniferous & 3.70 & 3 & -3 & 12 & 2 & 6 & 3.23 \\
Mixed & 3.24 & 2 & -7 & 13 & 1 & 5 & 4.94 \\
Deciduous & 1.00 & 2 & -5 & 7 & -3 & 2 & 3.55 \\
Ditch type & & & & & & & \\
Roadside & 3.00 & 2 & -7 & 9 & 2 & 5 & 3.30 \\
Drainage & 3.13 & 2.5 & -5 & 13 & 0.5 & 5.5 & 4.21 \\
Forest and ditch types & & & & & & & \\
Conif.-Road. & 4.38 & 4 & 1 & 9 & 1.5 & 7 & 3.07 \\
Conif.-Drain. & 3.48 & 3 & -3 & 12 & 2 & 5 & 3.31 \\
Mixed-Road. & 1.25 & 2 & -7 & 5 & 1 & 3 & 3.58 \\
Mixed.-Drain. & 5.00 & 4 & -2 & 13 & 1 & 8 & 5.50 \\
Decid.-Road. & 3.60 & 2 & 2 & 7 & 2 & 5 & 2.30 \\
Decid.-Drain. & $-1.17 *$ & -1.5 & -5 & 2 & -3 & 2 & 2.93 \\
\hline
\end{tabular}

* Statistically significant difference $(P=0.0500)$ versus drainage ditches in mixed forests
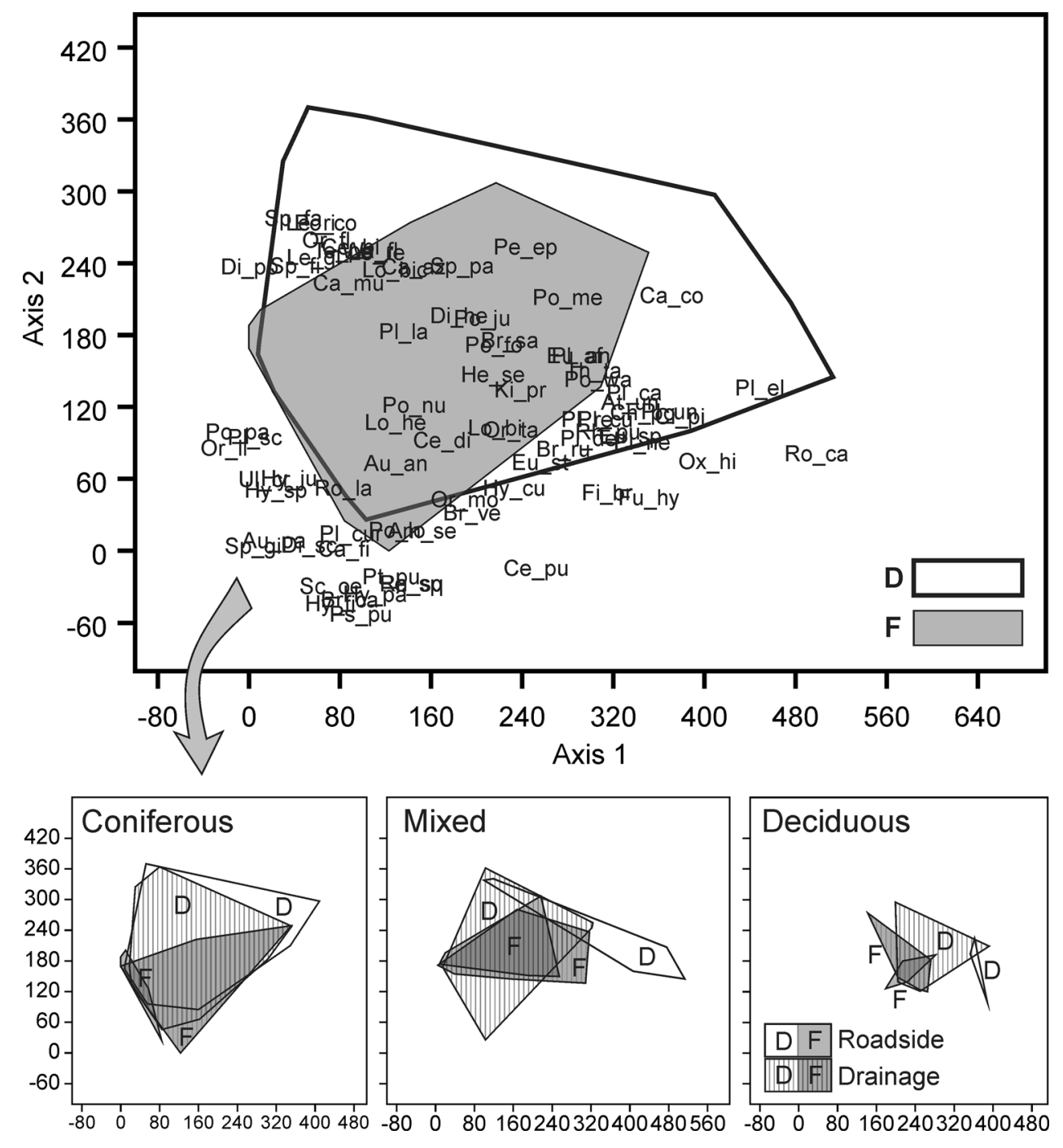

$-80 \quad 0 \quad 80160240320400480560$
Fig. 1 DCA ordination diagram with species abbreviations (as in the "Appendix") and convex hulls covering the points corresponding to the plots in the ditches $(D)$ and plots in the forests $(F)$. Points corresponding to particular plots are omitted. Convex hulls covering the plots in different kinds of forest (coniferous, mixed, deciduous) and different kinds of ditches (roadside, drainage) are extracted from the main diagram

8


Fig. 2 CCA ordination diagram of the analyzed data with environmental variables represented as arrows: $L$ light, $T$ temperature, $K$ continentality of climate, $F$ humidity, $R$ substrate $\mathrm{pH}$. Convex hulls are added separately for plots in ditches (1) and corresponding plots in forests (2). Points corresponding to particular plots are omitted. The eigenvalue of the first axis is $0.736(7.7 \%$ of total inertia) and of the second axis 0.577 (6.0\% of total inertia, for both $P=0.002$ ). Species names abbreviations as in "Appendix"; sporadic species have been omitted

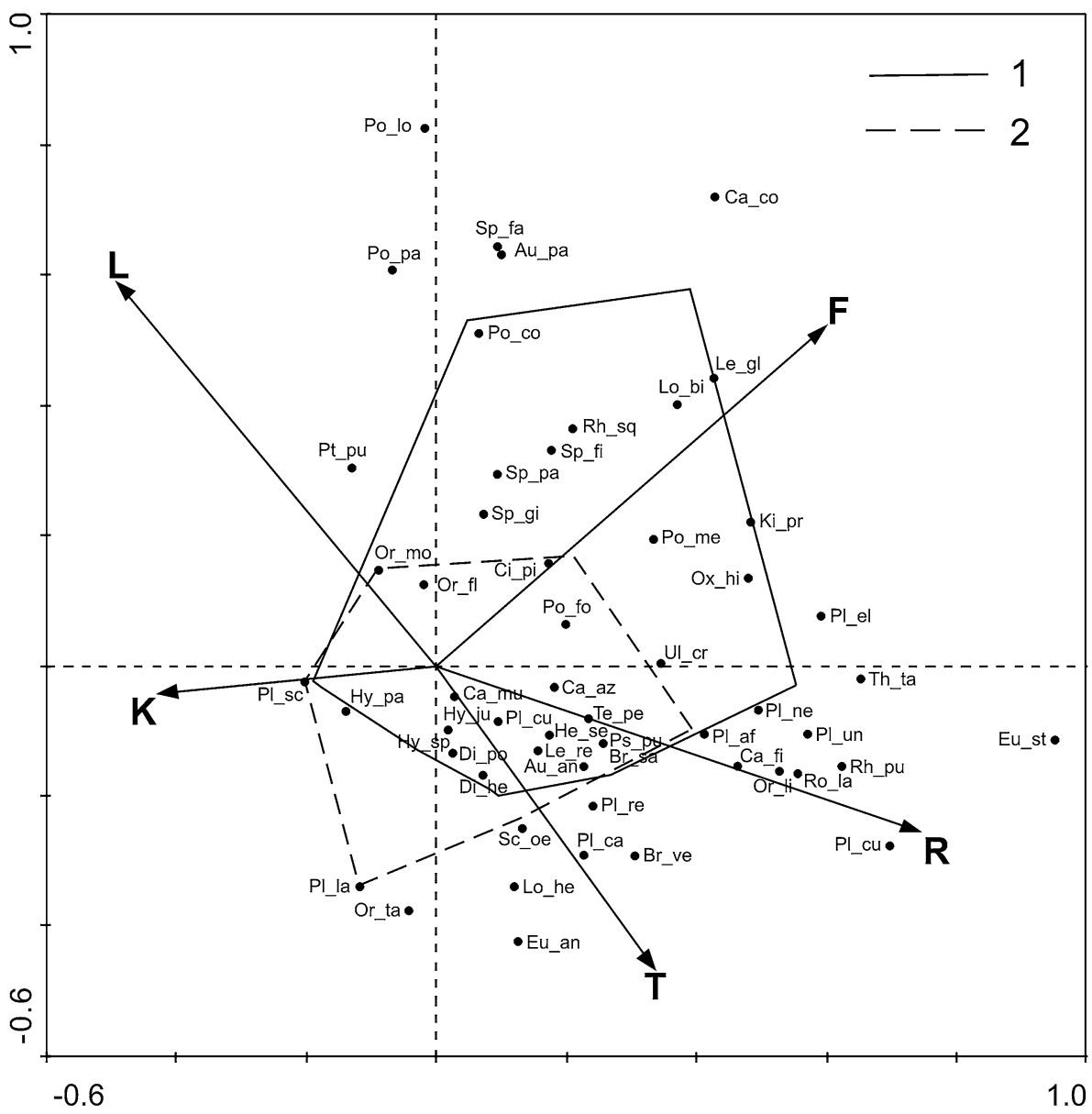

resulted from the anthropogenic structures that were present in the forests has previously been presented for vascular plants by Bergès et al. (2013), Baltzinger et al. (2011), Zielińska et al. (2013), among others. These authors claim that the main factor that is responsible for the increase in species richness is habitat diversification in this case. The analysis of bryophytes that is presented in this paper points to similar conclusions. The study plots were relatively small, and yet the bryophytes that were collected displayed rather varied habitat preferences. We found species that were adapted to relatively high humidity and light conditions in ditches. However, species that had the opposite preferences were also present. Ditches also provided habitats that were suitable for bryophytes, and especially liverworts, which occurred in initial habitats such as exposed mineral soils and at the same time for species that are typical for sites with well-developed vegetation. The strict correlation of bryophyte species diversification with habitat diversification has already been demonstrated by other authors (Żarnowiec 1995; Ohlson et al. 1997; Ingerpuu et al. 2001; Mills and Macdonald 2004, 2005; Klama 2002; von Oheimb et al. 2007; Madžule et al. 2012). This dependence stems from the fact that many bryophytes are accustomed to specific types of substrates and microhabitats (Cole et al. 2008; Madžule et al. 2012; Evans et al. 2012), and ditches provide different types of these.

In ditches, a much larger group of species was characterized by a low frequency than in the case of forests. A similar pattern was noted in the study of the impact of the anthropogenic structures on the vascular plants in forests (Peterken and Francis 1999; Zielińska et al. 2013). Similar to vascular plants, ditches not only enriched the species richness of forests as such but also contributed to high biodiversity by introducing species that are rare locally. Unlike vascular plants, however, species that are valuable not only locally but country-wise can be found among bryophytes. Among 18 of the rare and protected bryophytes that were recorded, an overwhelming majority (83\%) were found in ditches more frequently. Eight such species were completely absent from the forest plots.

As was demonstrated, ditches (both roadside and drainage) contributed to the diversification of bryophytes regardless of the stand type. The forest type and the type of ditch when considered separately did not have a statistically significant impact on the species richness; however, 
such a statistical significance was found for the interaction of the all of the factors that were taken into account. The DCA analysis, which was carried out in order to give us a better understanding of this phenomenon, showed that the species composition of the stand clearly influenced the floristic composition of bryophytes. The analysis with Morisita's index of similarity and Bray-Curtis similarity measure did not confirm any statistical importance of the observed pattern, and this was most likely due to the features of bryophytes. As relatively small organisms that are spread through spores, they can be ubiquitous. Among the patches of dominant species, single specimens of other species were found. Inclusion of these additional species into the analysis would lower the distinctiveness of the plots in the ditches and forests. Nevertheless, the same trend was observed for both types of ditches-the dissimilarity of ditch bryophytes against the bryophytes of control forest plots grew with an increase in the participation of deciduous trees in a stand. One significant cause of the dissimilarity is the features of the litter. Deciduous leaf litter may function as a physical barrier for many bryophytes, a barrier that inhibits the capture of light and throughfall precipitation by bryophytes (Beatty and Scholes 1988; Schumacher 2000; Hart and Chen 2006). It is also important that compared to coniferous forest litter, deciduous leaf litter is much higher in base cations and $\mathrm{pH}$, which increase soil fertility (Paré et al. 1993) and the rates of nutrient cycling (Côté et al. 2000). This in turn facilitates the growth of vascular plants which is the limiting factor for the occurrence of terricolous bryophytes (Ingerpuu et al. 1998; Hart and Chen 2006). Hence, bryophytes that prefer substrates that are composed of decaying wood debris and live tree trunks were predominant in the deciduous forest plots. No large trees occurred in ditches, and only their seedlings or specimens in the shrubbery layer existed, which in turn led to these plots being much poorer in epiphytic and epixylic species. On the other hand, epigeous species constituted a considerable proportion of the species that were found in ditches. In deciduous forests, these species can only grow in mineral soil that has been exposed as a result of the uprooting of trees or the activity of wild animals (Klama 1995, 2002; Żarnowiec 1995; von Oheimb et al. 2007). In managed forests, however, uprooted trees are a rare structural element, and thus, the participation of epigeous species in forest plots is rather small. Another factor could also contribute to the more numerous occurrences of terricolous bryophytes in ditches. Usually, long canopy gaps were observed over ditches, which could facilitate the growth of species that are more light demanding. As was demonstrated by Tinya et al. (2009), the occurrence of terricolous bryophytes is positively correlated with sunlight exposure, whereas light is not such a key factor for epixylic and epiphytic species. One more contributor to the dissimilarity of ditch and forest bryophytes could be the presence of stagnating water and the increased humidity that were observed during the studies in ditches. These conditions favored a higher incidence of hygrophilous species.

An altogether different situation was found in the ditches within coniferous forests. The flora of the bryophytes of the plots that were compared was very similar in this case. This was caused by the fact that the light conditions of coniferous forests were much closer to those in the ditches due to the significantly higher values of light transmission in pine forests in comparison with deciduous forests (Hart and Chen 2006). Additionally, evergreens do not shed leaves for the winter, which guarantees the stability of microclimatic conditions throughout the year (see Darell and Cronberg 2011). Coniferous forests favor the occurrence of a vast bryophyte layer (Barbier et al. 2008) and moss carpets, which are characteristic for such forests, are formed by a small group of competing species. These are mainly acidophilus taxa such as Pleurozium schreberi, Hylocomium splendens or Dicranum scoparium. The much greater similarity of habitat conditions in ditches and control plots than was the case for deciduous forests gave rise to the large pool of species that was present in both forests and ditches. In coniferous tree stands, the main factor that determines the diversification of epigeous bryophytes is the humidity regime (Stebel 2006). Hence, the presence of ditches in such forests is of primary importance for bryophytes that demand more humid substrates than those that are available in the surrounding forests. Under DCA analysis, mixed forests were characterized by features that were intermediate between deciduous and coniferous forest types. In comparison with coniferous forests, the dissimilarity of species in ditches and forests was greater although there was still a considerable number of common species.

On the one hand, the presence of a road that is lined with a ditch means the larger disturbance of site conditions and can negatively affect some of the more sensitive forest bryophytes, while on the other hand, it potentially creates a larger degree of habitat diversification, which can facilitate the occurrence of others. According to the species richness analysis, roadside ditches were characterized by a greater mean species richness than drainage ones only in deciduous forests. The obtained results are in accordance with findings of Smith et al. (2007) who claim that higher light levels within anthropogenic structures facilitate the growth of vascular plants and decrease the number of bryophytes. Only in the deciduous forests in which the species composition of the ditches differed from those in the corresponding plots the roadsides favoured bryophyte richness. 
The analysis based on ecological indicators (CCA) demonstrated the presence of bryophytes indicating a higher humidity in ditch habitats. Among the species that occurred exclusively in ditches, almost $40 \%$ were distinctly hygrophilous. The current level of groundwater in vast areas of the Central Poland Lowlands is much lower than in the past (Lipiński 2006), and marshland species are deemed to be the most endangered - among them a large group of peat mosses (Kucharski 2004; Kucharski et al. 2004; Żarnowiec et al. 2004). Drainage and roadside ditches that have not been cleared or dredged may function as an important preserve for this bryophyte group within forest flora. Liverworts (among others, Calypogeia), which demand a constant level of humidity and exposed mineral soil since they are poorly competitive against dense vascular plant carpets and especially grasses, were also found in ditches more frequently (Klama 1995, 2002; Fakiński et al. 1996; Frisvoll and Presto 1997). The strong presence of liverworts is significant in light of the fact that, unlike mosses, they are considered to be more susceptible to environmental transformation processes (Hodgetts 1996), especially improper and rapacious forest management. Ditches in managed forests are an important preserve for liverworts whose natural habitats have been heavily transformed. Of course, this is true when we are talking about the old ditches in areas in which it is impossible to recreate the site conditions prior to melioration. In forest complexes where backfilling ditches can result in the renewal of humid conditions, this would be the best option from the point of view of the protection of rare species. However, often forest habitats have been transformed too much or it is impossible to recreate wet site conditions for economic reasons. Our research shows that in such cases, the creation of ground depressions that cover a small area can help to protect the diversity of bryophytes.

It has been proven that pit and mound complexes, which are common elements of unmanaged forests, are important for the bryophyte richness of forest complexes (Jonsson and Esseenn 1990; Klama 1995, 2002; Żarnowiec 1995; Fakiński et al. 1996; Ouden and Alaback 1996; von Oheimb et al. 2007). The old ditches, which have been overgrown by plants, are somewhat similar to those naturally appearing disturbances because they are connected with the formation of similar types of microsites. The frequent incidents of soil disturbances on the banks of ditches and small pools of stagnant water on the bottoms were observed. Ditches are also connected with the creation of a canopy gaps. During an investigation of pit and mound complexes in Central Poland, many of the same species that were recorded in the study of ditches were found. These were, for example, Pellia epiphylla, Dicranella heteromalla, Pohlia nutans, Polytrichum commune and various species of the genus Sphagnum (Klama 1995; Żarnowiec 1995; Pawicka and Staniaszek-Kik unpublished data).

\section{Conclusions}

Ditches, especially those with stagnating water, are an important source of microhabitat diversification in managed forests. Their presence ensures the survival of rare and protected species that fail to find adequate substrates in contemporary managed forests. At the same time, no single alien species was recorded in the ditches. Therefore, the maintenance of small-scale structures that disturb the topography of the terrain affects the diversity of bryophytes in managed forests favorably.

Open Access This article is distributed under the terms of the Creative Commons Attribution 4.0 International License (http://creative commons.org/licenses/by/4.0/), which permits unrestricted use, distribution, and reproduction in any medium, provided you give appropriate credit to the original author(s) and the source, provide a link to the Creative Commons license, and indicate if changes were made.

\section{Appendix}

Bryophyte species encountered in the study plots. Abrr.abbreviations; threat category in Poland-V (vulnerable), protected species- $\mathrm{P} ; \mathrm{F}$-frequency counted with the formula $F=(n / N) \times 100 \%$ where n means the number of plots (in ditches or in forests) where the species was noted and $\mathrm{N}$ means the total number of plots under the analysis; substrates: S-soil, L-litter, DW-decaying wood (logs, stumps and fine woody debris), $\mathrm{T}$ - tree bases, $\mathrm{O}$ - other substrates (stones and animal bones).

\begin{tabular}{|c|c|c|c|c|c|}
\hline \multirow[t]{2}{*}{ Species } & \multirow[t]{2}{*}{ Abbr. } & \multirow{2}{*}{$\begin{array}{l}\text { Threat and } \\
\text { protected species }\end{array}$} & \multicolumn{2}{|l|}{$\mathrm{F}(\%)$} & \multirow[t]{2}{*}{ Substrates } \\
\hline & & & Forest plots & Ditches plots & \\
\hline \multicolumn{6}{|l|}{ Liverworts } \\
\hline Calypogeia azurea & Ca_az & & 1.6 & 18.0 & S, L, DW \\
\hline Calypogeia fissa & Ca_fi & $\mathrm{V}$ & 1.6 & - & $\mathrm{S}$ \\
\hline Calypogeia muelleriana & Ca_mu & & 3.3 & 11.5 & S, L, DW \\
\hline Cephalozia bicuspidata & Ce_bi & & 1.6 & 9.8 & S, L, DW, O \\
\hline
\end{tabular}




\begin{tabular}{|c|c|c|c|c|c|}
\hline \multirow[t]{2}{*}{ Species } & \multirow[t]{2}{*}{ Abbr. } & \multirow{2}{*}{$\begin{array}{l}\text { Threat and } \\
\text { protected species }\end{array}$} & \multicolumn{2}{|l|}{$\mathrm{F}(\%)$} & \multirow[t]{2}{*}{ Substrates } \\
\hline & & & Forest plots & Ditches plots & \\
\hline Cephaloziella divaricata & Ce_di & & 1.6 & 3.3 & $\mathrm{~S}$ \\
\hline Chiloscyphus polyanthos & Ch_po & & - & 1.6 & $\mathrm{~S}$ \\
\hline Lepidozia reptans & Le_re & & 4.9 & 21.3 & $\mathrm{~S}, \mathrm{~L}, \mathrm{DW}, \mathrm{O}$ \\
\hline Lophocolea bidentata & Lo_bi & & 4.9 & 14.8 & $\mathrm{~S}, \mathrm{~L}, \mathrm{DW}, \mathrm{T}$ \\
\hline Lophocolea heterophylla & Lo_he & & 68.9 & 50.8 & $\mathrm{~S}, \mathrm{~L}, \mathrm{DW}, \mathrm{T}, \mathrm{O}$ \\
\hline Lophozia bicrenata & Lo_bic & & - & 1.6 & $\mathrm{~S}, \mathrm{~L}$ \\
\hline Pellia epiphylla & Pe_ep & & - & 4.9 & $\mathrm{~S}, \mathrm{~L}$ \\
\hline Ptilidium pulcherrimum & $\mathrm{Pt} \_\mathrm{pu}$ & & 1.6 & 4.9 & DW, T \\
\hline Pellia sp. & Pe_sp & & - & 1.6 & $\mathrm{~S}$ \\
\hline \multicolumn{6}{|l|}{ Mosses } \\
\hline Amblystegium serpens & Am_se & & 4.9 & - & $\mathrm{DW}, \mathrm{T}, \mathrm{O}$ \\
\hline Atrichum undulatum & At_un & & 6.6 & 54.1 & S, DW \\
\hline Aulacomnium androgynum & Au_an & & 16.4 & 8.2 & $\mathrm{~S}, \mathrm{~L}, \mathrm{DW}, \mathrm{T}$ \\
\hline Aulacomnium palustre & $\mathrm{Au} \_\mathrm{pa}$ & $\mathrm{P}$ & - & 6.6 & $\mathrm{~S}, \mathrm{~L}, \mathrm{DW}$ \\
\hline Brachytheciastrum velutinum & Br_ve & & 18.0 & 16.4 & $\mathrm{~S}, \mathrm{~L}, \mathrm{DW}, \mathrm{T}, \mathrm{O}$ \\
\hline Brachythecium rutabulum & Br_ru & & 13.1 & 31.1 & $\mathrm{~S}, \mathrm{~L}, \mathrm{DW}, \mathrm{T}$ \\
\hline Brachythecium salebrosum & Br_sa & & 9.8 & 9.8 & $\mathrm{~S}, \mathrm{~L}, \mathrm{DW}, \mathrm{T}$ \\
\hline Bryum caespiticium & Br_ca & & 1.6 & - & S, DW \\
\hline Calliergon cordifolium & Ca_co & & - & 3.3 & $\mathrm{~L}$ \\
\hline Ceratodon purpureus & Ce_pu & & 1.6 & 3.3 & S, DW \\
\hline Cirriphyllum piliferum & Ci_pi & & - & 3.3 & $\mathrm{~S}$ \\
\hline Dicranella heteromalla & Di_he & & 26.2 & 65.6 & $\mathrm{~S}, \mathrm{~L}, \mathrm{DW}, \mathrm{T}, \mathrm{O}$ \\
\hline Dicranum polysetum & Di_po & $\mathrm{P}$ & 9.8 & 9.8 & S, L, DW \\
\hline Dicranum scoparium & Di_sc & $\mathrm{P}$ & 14.8 & 16.4 & $\mathrm{~S}, \mathrm{~L}, \mathrm{DW}, \mathrm{T}$ \\
\hline Eurhynchium angustirete & Eu_an & $\mathrm{P}$ & - & 1.6 & $\mathrm{~S}, \mathrm{~T}$ \\
\hline Eurhynchium striatum & Eu_st & $\mathrm{P}$ & 1.6 & - & $\mathrm{S}$ \\
\hline Fissidens bryoides & $\mathrm{Fi}$ br & & - & 6.6 & $\mathrm{~S}$ \\
\hline Funaria hygrometrica & Fu_hy & & - & 3.3 & $\mathrm{~S}$ \\
\hline Herzogiella seligeri & He_se & & 32.8 & 21.3 & $\mathrm{~S}, \mathrm{~L}, \mathrm{DW}, \mathrm{T}, \mathrm{O}$ \\
\hline Hylocomium splendens & Hy_sp & $\mathrm{P}$ & 1.6 & 6.6 & $\mathrm{~S}, \mathrm{~L}$ \\
\hline Hypnum cupressiforme & Hy_cu & & 36.1 & 14.8 & $\mathrm{~S}, \mathrm{~L}, \mathrm{DW}, \mathrm{T}, \mathrm{O}$ \\
\hline H. cupressiforme var. filiforme & Hy_fi & & 1.6 & 3.3 & $\mathrm{~T}$ \\
\hline Hypnum jutlandicum & Hy_ju & & 8.2 & 18.0 & $\mathrm{~S}, \mathrm{~L}, \mathrm{DW}, \mathrm{T}$ \\
\hline Hypnum pallescens & Hy_pa & & 13.1 & 3.3 & $\mathrm{~L}, \mathrm{DW}, \mathrm{T}, \mathrm{O}$ \\
\hline Kindbergia praelonga & Ki_pr & & 1.6 & 11.5 & $\mathrm{~S}, \mathrm{~L}, \mathrm{~T}$ \\
\hline Leptodictyum riparium & Le_ri & & - & 1.6 & $\mathrm{~L}$ \\
\hline Leucobryum glaucum & Le_gl & $\mathrm{P}$ & 1.6 & 3.3 & $\mathrm{~S}$ \\
\hline Orthodicranum flagellare & Or_fl & & 4.9 & 1.6 & S, DW \\
\hline Orthodicranum montanum & Or_mo & & 44.3 & 6.6 & $\mathrm{~S}, \mathrm{~L}, \mathrm{DW}, \mathrm{T}$ \\
\hline Orthodicranum tauricum & Or_ta & & 1.6 & - & DW. T \\
\hline Orthodontium lineare & Or_li & & 1.6 & - & $\mathrm{DW}, \mathrm{T}$ \\
\hline Oxyrrhynchium hians & Ox_hi & & - & 11.5 & $\mathrm{~S}$ \\
\hline Plagiomnium affine & Pl_af & & 24.6 & 59.0 & $\mathrm{~S}, \mathrm{~L}, \mathrm{DW}, \mathrm{T}$ \\
\hline Plagiomnium cuspidatum & Pl_cu & & - & 3.3 & $\mathrm{~S}$ \\
\hline Plagiomnium ellipticum & Pl_el & & - & 1.6 & $\mathrm{~S}, \mathrm{~L}$ \\
\hline Plagiomnium undulatum & Pl_un & & - & 6.6 & $\mathrm{~S}$ \\
\hline Plagiothecium cavifolium & Pl_ca & & - & 1.6 & $\mathrm{~S}$ \\
\hline
\end{tabular}




\begin{tabular}{|c|c|c|c|c|c|}
\hline \multirow[t]{2}{*}{ Species } & \multirow[t]{2}{*}{ Abbr. } & \multirow{2}{*}{$\begin{array}{l}\text { Threat and } \\
\text { protected species }\end{array}$} & \multicolumn{2}{|l|}{$\mathrm{F}(\%)$} & \multirow[t]{2}{*}{ Substrates } \\
\hline & & & Forest plots & Ditches plots & \\
\hline Plagiothecium curvifolium & Pl_cur & & 36.1 & 41.0 & $\mathrm{~S}, \mathrm{~L}, \mathrm{DW}, \mathrm{T}$ \\
\hline Plagiothecium denticulatum & Pl_de & & 23.0 & 55.7 & $\mathrm{~S}, \mathrm{~L}, \mathrm{DW}, \mathrm{T}, \mathrm{O}$ \\
\hline Plagiothecium laetum & Pl_la & & 47.5 & 34.4 & $\mathrm{~S}, \mathrm{~L}, \mathrm{DW}, \mathrm{T}, \mathrm{O}$ \\
\hline Plagiothecium nemorale & Pl_ne & & - & 1.6 & $\mathrm{~S}, \mathrm{O}$ \\
\hline Platygyrium repens & Pl_re & & 1.6 & 3.3 & DW \\
\hline Pleurozium schreberi & Pl_sc & $\mathrm{P}$ & 49.2 & 44.3 & $\mathrm{~S}, \mathrm{~L}, \mathrm{DW}, \mathrm{T}, \mathrm{O}$ \\
\hline Pohlia melanodon & Po_me & & 1.6 & 8.2 & $\mathrm{~S}$ \\
\hline Pohlia nutans & Po_nu & & 41.0 & 49.2 & $\mathrm{~S}, \mathrm{~L}, \mathrm{DW}, \mathrm{T}$ \\
\hline Pohlia wahlenbergii & Po_wa & & - & 1.6 & $\mathrm{~L}, \mathrm{DW}, \mathrm{T}, \mathrm{O}$ \\
\hline Polytrichastrum formosum & Po_fo & & 18.0 & 54.1 & $\mathrm{~S}$ \\
\hline Polytrichastrum longisetum & Po_lo & & 3.3 & 1.6 & $\mathrm{~S}$ \\
\hline Polytrichastrum pallidisetum & Po_pa & & 1.6 & - & $\mathrm{S}$ \\
\hline Polytrichum commune & Po_co & $\mathrm{P}$ & 3.3 & 16.4 & $\mathrm{~S}$ \\
\hline Polytrichum juniperinum & Po_ju & & - & 1.6 & $\mathrm{~S}$ \\
\hline Pseudoscleropodium purum & Ps_pu & $\mathrm{P}$ & 4.9 & 16.4 & $\mathrm{~S}, \mathrm{~L}, \mathrm{~T}$ \\
\hline Rhizomnium punctatum & $\mathrm{Rh} \_p u$ & & - & 4.9 & $\mathrm{~S}, \mathrm{~L}$ \\
\hline Rhytidiadelphus squarrosus & Rh_sq & $\mathrm{P}$ & - & 1.6 & $\mathrm{~L}$ \\
\hline Rosulabryum capillare & Ro_ca & & - & 1.6 & $\mathrm{~S}$ \\
\hline Rosulabryum laevifilum & Ro_la & & 1.6 & 1.6 & $\mathrm{~T}$ \\
\hline Sciuro-hypnum oedipodium & Sc_oe & & 37.7 & 42.6 & $\mathrm{~S}, \mathrm{~L}, \mathrm{DW}, \mathrm{T}$ \\
\hline Sphagnum fallax & Sp_fa & $\mathrm{P}$ & 1.6 & 21.3 & $\mathrm{~S}$ \\
\hline Sphagnum fimbriatum & Sp_fi & $\mathrm{P}$ & - & 3.3 & $\mathrm{~S}$ \\
\hline Sphagnum girgensohnii & Sp_gi & $\mathrm{P}$ & - & 1.6 & $\mathrm{~S}$ \\
\hline Sphagnum palustre & Sp_pa & $\mathrm{P}$ & - & 1.6 & $\mathrm{~S}$ \\
\hline Tetraphis pellucida & Te_pe & & 26.2 & 18.0 & $\mathrm{~S}, \mathrm{~L}, \mathrm{DW}, \mathrm{T}$ \\
\hline Thuidium tamariscinum & Th_ta & $\mathrm{P}$ & - & 1.6 & $\mathrm{~S}$ \\
\hline Ulota crispa & Ul_cr & $\mathrm{P}$ & - & 1.6 & DW \\
\hline Warnstorfia fluitans & Wa_fl & & - & 3.3 & $\mathrm{~S}$ \\
\hline Eurhynchium sp. & Eu_sp & & - & 1.6 & $\mathrm{~S}$ \\
\hline
\end{tabular}

\section{References}

Andersson LI, Hytteborn H (1991) Bryophytes and decaying wooda comparison between managed and natural forest. Holarct Ecol 14:121-130

Baltzinger M, Archaux F, Gosselin M, Chevalier R (2011) Contribution of forest management artefacts to plant diversity at a forest scale. Ann For Sci 68:395-406

Barbier S, Gosselin F, Balandier P (2008) Influence of tree species on understory vegetation diversity and mechanisms involved. A critical review for temperate and boreal forests. For Ecol Manag 254(1):1-15

Beatty SW, Scholes ODV (1988) Leaf litter effect on plant species composition of deciduous forest treefall pits. Can J For Res 18:553-559

Bergès L, Chevalier R, Avon C (2013) Influence of forest road, roadsurfacing material and stand age on floristic diversity and composition in a nutrient-poor environment. Appl Veg Sci $16: 470-479$

Cole HA, Newmaster SG, Bell FW, Pitt D, Stinson A (2008) Influence of microhabitat on bryophyte diversity in Ontario mixedwood boreal forest. Can J For Res 38(7):1867-1876. doi:10.1139/X08-036

Commarmot B, Bachofen H, Bundziak Y, Burgi A, Ramp B, Shparyk Y, Sukhariuk D, Viter R, Zingg A (2005) Structure of virgin and managed beech forests in Uholka (Ukraine) and Sihlwald (Switzerland): a comparative study. For Snow Landsc Res 79:45-56

Côté L, Brown S, Paré D, Fyles JW, Bauhus J (2000) Dynamics of carbon and nitrogen mineralization in relation to stand type, stand age and soil texture in the boreal mixedwood. Soil Biol Biochem 32:1079-1090

Darell P, Cronberg N (2011) Bryophytes in black alder swamps in south Sweden: habitat classification, environmental factors and life-strategies. Lindbergia 34:9-29

Düll R (1992) Zeigerwerte von Laub- nad Lebermoosen. In: Ellenberg H, Weber HE, Düll R, Wirth V, Werner W (eds) Zeigerwerte von Pflanzen in Mitteleuropa. Scripta Geobot 18:175-214

Evans SA, Charles BH, McKenzie D (2012) The contributions of forest structure and substrate to bryophyte diversity and abundance in mature coniferous forests of the Pacific Northwest. Bryologist 115(2):278-294. doi:10.1639/0007-2745-115.2.278 
Faliński JB, Mułenko W, Żarnowiec J, Klama H, Załuski T (1996) The colonisation of fallen tree sites by green plant of fungi. In: Faliński JB, Mułenko W (eds) Cryptogamous plants in the forest communities of Białowieża National Park (Project CRYPTO). Phytocoenosis 8(N.S.) Arch Bot 6:147-150

Flory SL, Clay K (2009) Effects of roads and forest successional age on experimental plant invasions. Biol Conserv 142:2531-2537

Forman RTT, Sperling D, Bissonette JA, Clevenger AP, Cutshall CD, Dale VH, Fahrig L, France R, Goldman CR, Heanue K, Jones JA, Swanson FJ, Turrentine T, Winter TC (2003) Road ecology: science and solutions. Island Press, Washington, DC

Franklin JF, Spies TA, Van Pelt R, Carey AB, Thornburgh DA, Berg DR, Lindenmayer DB, Harmon ME, Keeton WS, Shaw DC, Bible K, Chen J (2002) Disturbances and structural development of natural forest ecosystems with structural implications, using Douglas-fir forests as an example. For Ecol Manag 155(1-3):399-423

Frisvoll AA, Presto T (1997) Spruce forest bryophytes in central Norway and their relationship to environmental factors including modem forestry. Ecography 20:3-18

Fudali E (2006) Influence of city on the floristical and ecological diversity of Bryophytes in parks and cemeteries. Biodivers Res Conserv 1-2:131-137

Gustafsson L, Hallingbäck T (1988) Bryophyte Flora and vegetation of managed and virgin coniferous forests in South-West Sweden. Biol Conserv 44:283-300

Hammer Ø, Harper DAT, Ryan PD (2001) Past: paleontological statistics software package for education and data analysis. Palaeontol Electron 4(1):1-9

Härdtle W, von Oheimb G, Westphal Ch (2003) The effects of light and soil conditions on the species richness of the ground vegetation of deciduous forests in northern Germany (SchleswigHolstein). For Ecol Manag 182:327-338

Hart SA, Chen HYH (2006) Understory vegetation dynamics of North American boreal forests. Crit Rev Plant Sci 25:381-397

Herben T (1987) Bryophytes in grassland vegetation sample plots: what is their correlation with vascular plants. Folia Geobot Phytotaxon 22:35-41

Hill MO (1992) Mixtures as habitats for plants. In: Cannell MGR, Malcolm DC, Robertson PA (eds) The ecology of mixed-species stands of trees. Blackwell Scientific Publications, Oxford, pp 301-302

Hillman GR (1992) Some hydrological effects of peatland drainage in Alberta's boreal forest. Can J For Res 22:1588-1596

Hodgetts NG (1996) Threatened bryophytes in Europe. Anal Inst Biol Ser Bot 67(1):183-200

Hokkanen P (2006) Environmental patterns and gradients in the vascular plants and bryophytes of eastern Fennoscandian herbrich forest. For Ecol Manag 229(1-3):73-87

Humphrey JW, Davey S, Peace AJ, Ferris R, Harding K (2002) Lichens and bryophyte communities of planted and semi-natural forests in Britain: the influence of site type, stand structure and deadwood. Biol Conserv 107:165-180

Ingerpuu N, Kull K, Vellak K (1998) Bryophyte vegetation in wooded meadow: relationship with phanerogam diversity and responses to fertilisation. Plant Ecol 134:163-171

Ingerpuu N, Vellak K, Kukk T, Pärtel M (2001) Bryophyte and vascular plant species richness in boreo-nemoral moist forests and mires. Biodivers Conserv 10:2153-2166

Jonsson BG, Esseenn P-A (1990) Treefall disturbance maintains high bryophyte diversity in a boreal spruce forest. J Ecol 78:924-936

Jukoniene I (2008) The impact of anthropogenic habitats on rare bryophyte species in Lithuania. Folia Cryptog Est 44:55-62

Klama H (1995) Hepaticopsida. In: Faliński JB, Mułenko W (eds) Cryptogamous Plants in the Forest Communites of Białowieża
National Park. Phytocoenosis 7 (N.S.). Archivum Geobotanicum 4:63-74

Klama H (2002) Distribution patterns of liverworts (Marchantiopsida) in natural forest communities (Białowieża Primeval Forest, NE Poland). University of Bielsko-Biała, Bielsko-Biała, ss. xiv + 278

Klama H (2006) Systematic catalogue of Polish liverwort and hornwort taxa. In: Szweykowski J (ed) An annotated checklist of Polish Liverworts and Hornworts. W. Szafer Institute of Botany PAN, Krakow, pp 83-100

Kucharski L (2004) Floristical diversity of wetlands in Central Poland-conditions and changes. Teka Kom Ochr Kszt Środ Przyr 1:116-121

Kucharski L, Michalska-Hejduk D, Kołodziejek J (2004) Transitional and raised bogs in central Poland-condition and protection. In: Wołejko L, Jasnowska J (eds) The Future of Polish Mires. Soc. Scient. Stetinensis, Agricult. Univ. Szczecin, pp 113-117

Kuuluvainen T, Penttinen A, Leinonen K, Nygren M (1996) Statistical opportunities for comparing stand structural heterogeneity in managed and primeval forests: an example from boreal spruce forest in southern Finland. Silva Fennica $30: 315-328$

Lipiński J (2006) Zarys rozwoju oraz produkcyjne i środowiskowe znaczenie melioracji w świetle badań [An outline of land amelioration development and its productive and environmental significance in view of studies]. Acta Scientarum Polonarum Formatio Circumiectus 5(1):3-15 (in Polish)

Londo G (1975) Dezimalskala für die Vegetationskundliche Aufnahme von Dauerquadraten. In: Schmidt W (ed) Sukzessionsforschung. Berichte der Internationalen Symposien der Internationalen Vereinigung für Vegetationskunde Herausgegeben von Reinhold Tüxen. Berlin 16-19.04.1973, pp 613-617

Madžule L, Brūmelis G, Tjarve D (2012) Structures determining bryophyte species richness in a managed forest landscape in boreo-nemoral Europe. Biodivers Conserv 21:437-450

Márialigeti S, Németh B, Tinya F, Ódor P (2009) The effects of stand structure on ground-floor bryophyte assemblages in temperate mixed forests. Biodivers Conserv 18:2223-2241

Matuszkiewicz W (2001) Guide to the determination of plant communities in Poland. PWN Press, Warsaw (in Polish)

Mills SE, Macdonald SE (2004) Predictors of moss and liverwort species diversity of microsites in conifer-dominated boreal forest. J Veg Sci 15:189-198

Mills SE, Macdonald SE (2005) Factors influencing bryophyte assemblage at different scales in the western Canadian boreal forest. Bryologist 108(1):86-100

Ochyra R, Żarnowiec J, Bednarek-Ochyra H (2003) Census catalogue of Polish mosses. Biodiversity of Poland, vol 3. Polish Academy of Sciences, Institute of Botany, Kraków, pp 1-372

Ódor P, Király I, Tinya F, Bortignon F, Nascimbene J (2013) Patterns and drivers of species composition of epiphytic bryophytes and lichens in managed temperate forests. For Ecol Manag 306:256-265. doi:10.1016/j.foreco.2013.07.001

Ohlson M, Söderström L, Hörnberg G, Zackrisson O, Hermansson J (1997) Habitat qualities versus long-term continuity as determinants of biodiversity in boreal old-growth swamp forests. Biol Conserv 81:221-231

Ouden J, Alaback PB (1996) Successional trends and biomass of mosses on windthrow mounds in the temperate rainforests of Southeast Alaska. Plant Ecol 124(2):115-128

Paillet Y, Bergès L, Hjältén $\mathrm{J}$, Ódor $\mathrm{P}$, Avon $\mathrm{C}$, BernhardtRömermann M, Bijlsma R-J, De Bruyn L, Fuhr M, Grandin U, Kanka R, Lundin L, Luque S, Magura T, Matesanz S, Mészáros I, Sebastià M-T, Schmidt W, Standovár T, Tóthmérész B, Uotila A, Valladares F, Vellak K, Virtanen R (2010) Does biodiversity 
differ between managed and unmanaged forests? A metaanalysis on species richness in Europe. Conserv Biol 24:101-112

Paré D, Bergeron Y, Camire C (1993) Changes in the forest floor of Canadian southern boreal forest after disturbance. J Veg Sci 4:811-818

Peterken GF, Francis JL (1999) Open spaces as habitats for vascular ground flora species in the woods of central Lincolnshire, UK. Biol Conserv 91:55-72

Ricklefs RE, Lovette IJ (1999) The role of island area per se and habitat diversity in the species-area relationship of four lesser Antillean faunal groups. J Anim Ecol 68:1142-1160

Roy V, Plamondon AP, Bernier P (2000) Draining forested wetland cutovers to improve seedling root zone conditions. Scand J For Res 15:58-67

Schumacher A (2000) Die Ökologie der Moose in mitteleuropäischen Buchenwäldern unter dem Einfluß der Forstwirtschaft. Diss Bot 331:1-176

Slack N (1990) Bryophytes and ecological niche theory. Bot J Linn Soc 104:187-213

Smith GF, Iremonger S, Kelly DL, O'Donoghue S, Mitchell FJG (2007) Enhancing vegetation diversity in glades, rides and roads in plantation forests. Biol Conserv 136(2):283-294

Stebel A (2006) The mosses of the Beskidy Zachodnie as a paradigm of biological and environmental changes in the flora of the Polish Western Carpathians. Habilitation Thesis 17/2006. Medical University of Silesia in Katowice, Sorus, Katowice-Poznań

Steinmann K, Eggenberg S, Wohlgemuth T, Linder HP, Zimmermann NE (2011) Niches and noise-disentangling habitat diversity and area effect on species diversity. Ecol Complex 8(4):313-319. doi:10.1016/j.ecocom.2011.06.004
Ter Braak CJF, Smilauer P (2002) CANOCO Reference Manual and CanoDraw for Windows User's Guide: Software for Canonical Community Ordination (version 4.5), Ithaca NY, USA: www. canoco.com, 2002 (Microcomputer Power)

Tinya F, Márialigeti S, Király I, Németh B, Ódor P (2009) The effect of light conditions on herbs, bryophytes and seedlings of temperate mixed forests in Örség, Western Hungary. Plant Ecol 204(1):69-81

Vellak K, Paal J (1999) Diversity of bryophyte vegetation in some forest types in Estonia: a comparison of old unmanaged and managed forests. Biodivers Conserv 8:1595-1620

Vellak K, Paal J, Liira J (2003) Diversity and distribution pattern of bryophytes and vascular plants in a boreal spruce forest. Silva Fennica 37(1):3-13

von Oheimb G, Friedel A, Bertsch A, Härdtle W (2007) The effects of windthrow on plant species richness in a Central European beech forest. Plant Ecol 191:47-65

Żarnowiec J (1995) Bryopsida. In: Faliński JB, Mułenko W (eds) Cryptogamous Plants in the Forest Communities of Białowieża National Park. Phytocoenosis 7 (N.S.). Archivum Geobotanicum 4:47-61

Żarnowiec J, Stebel A, Ochyra R (2004) Threatened moss species in the Polish Carpathians in the light of a new Red list of mosses in Poland. [W:] Stebel A, Ochyra R (red.), Bryological studies in the Western Carpathians. Sorus, Poznań, s.: 9-28

Zielińska KM, Misztal M, Zielińska A, Żywiec M (2013) Influence of ditches on plant species diversity in the managed forests of Central Poland. Baltic For 19(2):270-279 